\title{
Determination of Phenolic Content, Ascorbic Acid, Antioxidant Activity and Antimicrobial Activity of Selected Fruit Waste
}

\author{
Syeril Nurfatihah Suhaimi ${ }^{1}$, Erniee Eileen Rizlan $\operatorname{Ross}^{1}$, Ishak Zubir ${ }^{2}$, Shanti Navaratnam ${ }^{1}$, Raseetha Siva ${ }^{1}$ * \\ ${ }^{1}$ Faculty of Applied Sciences, Universiti Teknologi MARA, 40450 Shah Alam Selangor \\ ${ }^{2}$ Cocoa Innovative and Technology Centre, Malaysian Cocoa Board, Lot 12621, Kawasan Perindustrian Nilai, 71800 Nilai, Negeri \\ Sembilan \\ *Corresponding author E-mail: raseetha@salam.uitm.edu.my
}

\begin{abstract}
The aim of this study was to determine the total phenolic content (TPC), antioxidant activity, ascorbic acid content and antimicrobial activity of extracts obtained from cocoa pod husk, banana peel and pineapple peel. Banana peel had significantly highest total phenolic content (154.50 mg GAE/g) followed by pineapple peel (140.37 mg GAE/g) and cocoa pod husk (114.08 mg GAE/g). Antioxidant activity of these samples measured using DPPH assays. Banana peel showed significantly higher DPPH scavenging activity (95.74\%) compared to pineapple peel (84.96\%) and cocoa pod husk (68.33\%). Pineapple peel resulted in significantly higher (44.19 ppm) ascorbic acid as measured using High performance liquid chromatography (HPLC) method compared to banana peel (28.56 ppm). Cocoa pod husk, banana peel and pineapple peel were observed for antimicrobial activity against Escherichia coli, Staphylococcus aureus and penicillium. Samples extract at different concentrations in E. coli, S.aureus and penicillium-seeded Mueller-Hinton agar medium, resulted zone of inhibition after $24 \mathrm{~h}$ incubation in $37^{\circ} \mathrm{C}$ for bacteria and $72 \mathrm{~h}$ incubation in $28^{\circ} \mathrm{C}$. Banana peel at 20 and $25 \mathrm{mg} / \mathrm{ml}$ against S.aureus resulted in zone of inhibition $9.67,11.67 \mathrm{~mm}$ and cocoa pod husk with $8.00,9.67 \mathrm{~mm}$ respectively. Cocoa pod husk at 15,20 and $25 \mathrm{mg} / \mathrm{ml}$ against E.coli resulted in zone of inhibition 7.33, 9.33 and $10.33 \mathrm{~mm}$ and banana peel with $6.67,7.33$ and $7.67 \mathrm{~mm}$ respectively. Pineapple peel does not showed any inhibition zone against tested bacteria and fungi.
\end{abstract}

Keywords: antioxidant; banana peel; cocoa pod husk; pineapple peel; phenolics; antimicrobial

\section{Introduction}

Food industry uses fruits as one of the raw material for food production where the main wastes of the production are the peel and the seed of the fruit. Utilization of waste from fruits has been increased and also important as it could be utilized for further industrial purposes such as extraction of functional ingredients. Functional properties of some peel components such as pectin, antioxidants, flavonoids, carotenoids and other bioactive compounds can be valorised [1]. Waste material from fruits may be in form of leaves, seed, peels and pulp. About 25 to $30 \%$ of non-edible product are yield by fruits and vegetables. These waste material can be successfully used as source of phytochemical and antioxidant [2]. Peel and seed of some fruits have the potential to be utilized as a resource of bioactive compounds such as natural antioxidants due to high content of phenolic compounds [3]. Antimicrobial play an important role in fruits that provide protection of the fruits against pathogenic microorganism [2].

Cocoa (Theobroma cocoa L.) pod husk comes from cocoa industry. It is thrown away after the seed is removed. Every ton of dry cocoa bean produced, 10 tons of $\mathrm{CPH}$ are generated which can cause serious problems in waste management [4]. Phenolic content of cocoa gives good effect towards ageing, oxidative stress, atherosclerosis and blood pressure regulation [5]. Utilisation of by-products from banana plant can reduce environmental issue [6]. Banana peels is part of the banana fruit that has ability to serve as antibacterial agent against microorganism but it is not widely studied and contain bioactive compound such as flavonoids, tannins and terpenoids [7]. Pineapple (Ananas comosus L.) by-product consist of residual pulp, peel, stem and leaves that are generated from the processing of pineapple [8]. Pineapple peel represent about $10 \%(\mathrm{w} / \mathrm{w})$ of the weight of the original fruit [9].

Phenolic compounds can exhibit wide range of physiological properties and occurs mainly in plant foods i.e. anti-allergenic, anti-inflammantory, anti-microbial as well as antioxidant [10]. Antioxidant has ability to inhibit or delay oxidation process [11]. Synthetic antioxidants have shown toxic effect that can cause liver damage and also mutagenesis [10]. Antimicrobial are agent that are able to inhibit growth of microorganism especially pathogenic microorganisms. Food poisoning is related to the bacteria contamination on foods [7]. For example, gram negative bacteria are the most common bacteria that cause food poisoning. Gram negative bacteria that contribute to food poisoning includes Salmonella typhi, Escherichia coli and Pseudomonas aeruginosa. On the other hand, gram positive bacteria also can cause food poisoning which includes Staphylococcus aureus and Bacillus spp. Thus, the aim of this study was to determine the total phenolic content (TPC), antioxidant activity using DPPH assay, ascorbic acid content, chlorogenic acid content, and antimicrobial activity of extracts obtained from cocoa pod husk, banana peel and pineapple peel. 


\section{Materials and methods}

\subsection{Preparations of samples}

The cocoa waste sample (cocoa pod husk) was collected from Lembaga Koko Malaysia (Jengka, Pahang) and banana and pineapple peel was collected from local market Seksyen 6, Shah Alam. Fruit waste samples (cocoa pod husk, banana peel and pineapple peel) was dried by using cabinet dryer $\left(60^{\circ} \mathrm{C}, 24\right.$ hours $)$ then grind to fine powder. Ground samples was extracted with $70 \%$ aqueous ethanol for 2 hours at $50{ }^{\circ} \mathrm{C}$ using an orbital shaker [5]. Mixture then was filtered through filter paper (Whatman No 1) using a funnel. The filtrate was stored in freezer $\left(-20^{\circ} \mathrm{C}\right)$ for further used.

\subsection{Total phenolic content}

The total phenolic content of the fruit waste was determined by the Folin-Ciocalteu method [12]. $200 \mu \mathrm{L}$ of the extracts was mixed with $1.5 \mathrm{~mL}$ Folin-Ciocalteu reagent. The mixture was allowed to stand at room temperature for 5 minutes. $1.5 \mathrm{~mL}$ of sodium bicarbonate solution $(0.566 \mathrm{M})$ was added. After 90 minutes, the absorbance was measured by using spectrophotometer at $725 \mathrm{~nm}$. Results expressed as gallic acid equivalents.

\subsection{Ascorbic acid and chlorogenic acid content}

The sample extracts prepared in Section 2.1 was further subjected to rotavapouriser to remover remaining ethanol solvent and used for ascorbic acid and chlorogenic acid analysis. The analysis was carried-out using a combination of chromatographic separation Agilent HPLC 1200 series as described previously [13]. The chromatographic separation was performed using GL Sciences Inertsustain Column C-18 $(250 \mathrm{~mm} \times 4.6 \mathrm{~mm}$, i.d., $5 \mathrm{~mm})$ and temperature set at $40^{\circ} \mathrm{C}$ for both left and right side. The liquid chromatography (LC) parameters such as injection volume was set for 5ul at auto sampler (G1367D), binary pump was set till 45.01 min with post time $4.99 \mathrm{~min}$, flow rate $0.6 \mathrm{ml} / \mathrm{min}$, minimum pressure $1 \mathrm{bar}$ and maximum pressure $400 \mathrm{bar}$, max flow gradient 100 $\mathrm{ml} / \mathrm{min}$. Two set of solvents used known as solvent A and B. Solvent $\mathrm{A}$ and solvent $\mathrm{B}$ consist of $\mathrm{H}_{2} \mathrm{O}$ : $\mathrm{MeOH}(8: 2)$ with $0.1 \%$ formic acid. Combination of both solvent in LC system was set at a ratio of solvent $\mathrm{A}$ : solvent $\mathrm{B}, 95: 5$ with gradient elution: from $5 \%$ solvent B at $0 \mathrm{~min}, 55 \%$ solvent B at $30 \mathrm{~min}$ to $100 \%$ solvent B at $40 \mathrm{~min}$. The eluent was monitored with a diode array detector at 254 and $280 \mathrm{~nm}$, respectively, for ascorbic acid and chlorogenic acid. Ascorbic acid and chlorogenic acid was used as standard.

\subsection{Antioxidant activity using DPPH radical scavenging assay}

Antioxidant activity was determined by using method described previously [14]. Different dilutions of the fruit waste extract was prepared $(50,100,150,200,250 \mu \mathrm{g} / \mathrm{mL})$. DPPH solution was also prepared by dissolving $6.0 \mathrm{mg}$ of DPPH in $100 \mathrm{~mL}$ methanol Then, $1 \mathrm{~mL}$ of extract from each dilution was added into the test tube containing $2 \mathrm{~mL}$ of DPPH solution. Control was prepared by adding $1 \mathrm{~mL}$ of ethanol to $2 \mathrm{~mL}$ of DPPH solution. Gallic acid were used as standards. The mixture was shaken vigorously and was left to stand in the dark for $30 \mathrm{~min}$. The absorbance of the resulting solution was measured using spectrophotometer at 517 nm.

\subsection{Antimicrobial activity}

Antimicrobial activity of the samples was tested by using disc diffusion method. After incubation, zone of inhibition was identified from circular transparent area that is free from bacteria colonies. The test was carried out using cocoa pod husk, banana peel and pineapple peel extracts at concentration of 15,20 and 25 $\mathrm{mg} / \mathrm{mL}$.

\subsubsection{Minimum inhibition concentration (MIC)}

MIC is the lowest sample concentration capable of inhibiting any visible growth of the germ. It measures a bacteriostatic effect and does not provide information on the status of the bacterial population. MIC was measured by the method described [15] using 96well microplates according to the following steps: $200 \mu \mathrm{L}$ of cocoa waste, banana and pineapple peel extract was deposited in columns 3; a dilution series of factor 2 was carried out by taking $100 \mu \mathrm{L}$ of column No. 3 and adding them in column No. 4 and so on to column No. 12. The last $100 \mu \mathrm{L}$ of the wells of column No. 12 were discarded. Then $20 \mu \mathrm{L}$ of the microbial suspension were deposited in the various wells to which $10 \mu \mathrm{L}$ of resazurin (growth indicator which is initially blue and turns pink in case of cell growth) was added. In column 1 an antibiotic (ampicilin) was used (positive control). The test was repeated three times. The broth dilution from MIC test that showed clear turbidity was chosen for MBC test.

\subsubsection{Minimum bactericidal concentration (MBC)}

Minimum bactericidal concentration (MBC) is the minimum extract concentration that caused bacterial elimination. The clear broth dilution from MIC was sub-cultured onto Muller Hilton $(\mathrm{MH})$ agar using streak plate method and incubated for 24 hours at $37{ }^{\circ} \mathrm{C}$. After the incubation, the $\mathrm{MH}$ agar plate was observed for any growth of bacteria. The selected concentration of ethanolic extract of fruit waste used for $\mathrm{MBC}$ is said to be bactericidal if the $\mathrm{MH}$ agar plate shows no growth of organism after incubation.

\subsection{Statistical analysis}

All data was expressed as mean \pm standard deviation. All statistical analysis was conducted by using SPSS 16.0 (Statistical Programme for Scientific Students) for windows. Tukey's multiplerange test was used to access the differences between means. A significant difference was considered at the level of $p<0.05$.

\section{Results and discussion}

\subsection{Total phenolic content, antioxidant, ascorbic acid and chlorogenic acid in selected fruit waste}

The results shown that banana peel has the highest total phenolic content with $154.50 \pm 1.04 \mathrm{mg} \mathrm{GAE} / \mathrm{g}$ dried weight as indicated in Table 1. Comparing the results obtained for ethanolic extract of banana peel [16], total phenolic content obtained was lower with $15.21 \pm 0.09 \mathrm{mg}$ GAE$/ \mathrm{g}$ dry weight. Total phenolic content of pineapple peel obtained was $140.37 \pm 1.10 \mathrm{mg} \mathrm{GAE} / \mathrm{g}$. TPC recorded for pineapple peel was slightly lower than banana peel. Study conducted by [17] found that the TPC of pineapple peel was $7.89 \mathrm{mg} \mathrm{GAE} / \mathrm{g}$ or dry weight and $148.91 \mathrm{mg} \mathrm{GAE} / 100 \mathrm{~g}$ of fresh weight. For cocoa pod husk, the total phenolic content obtained was $114.08 \pm 2.33 \mathrm{mg} \mathrm{GAE} / \mathrm{g}$. The TPC of cocoa pod husk was very lower than banana and pineapple peel. Highest TPC of cocoa pod husk obtained was $49.54 \pm 3.69 \mathrm{mg} \mathrm{GAE} / \mathrm{g}$ [18]

Table 1: Total phenolic content, ascorbic acid and chlorogenic acid of selected fruit waste

\begin{tabular}{cccc}
\hline Sample & $\begin{array}{c}\text { Total } \\
\text { phenolic con- } \\
\text { tent } \\
(\mathbf{m g ~ G A E} / \mathbf{g})\end{array}$ & $\begin{array}{c}\text { Ascorbic acid } \\
(\mathbf{p p m})\end{array}$ & $\begin{array}{c}\text { Chlorogenic } \\
\text { acid } \\
(\mathbf{p p m})\end{array}$ \\
\hline $\begin{array}{c}\text { Banana } \\
\text { peel }\end{array}$ & $154.50 \pm 1.04^{\mathrm{a}}$ & $28.56 \pm 8.59^{\mathrm{b}}$ & 0 \\
$\begin{array}{c}\text { Pineapple peel } \\
\text { Cocoa pod }\end{array}$ & $140.37 \pm 1.10^{\mathrm{b}}$ & $44.19 \pm 4.93^{\mathrm{a}}$ & $2.72^{\mathrm{a}}$ \\
\hline
\end{tabular}


husk

As for antioxidant activity measured using DPPH assay, scavenging activity increased as the concentration of extracts increased. At concentration 250 ppm, banana peel extract showed highest scavenging activity with $95.74 \%$. [16] found that the scavenging activity of banana peel extract at $50 \mu \mathrm{g} / \mathrm{mL}$ was $40.45 \%$. For pineapple peel, at highest concentration $250 \mathrm{ppm}$, it showed significantly lower scavenging activity than banana peel with $84.96 \%$. Cocoa pod husk showed lowest scavenging activity even at highest concentration with $68.33 \%$. Highest scavenging activity of cocoa pod husk was $79.6 \%$ [18]. One of the reasons for differences of antioxidant activity maybe because of variation of phenolic content in the waste extracts.

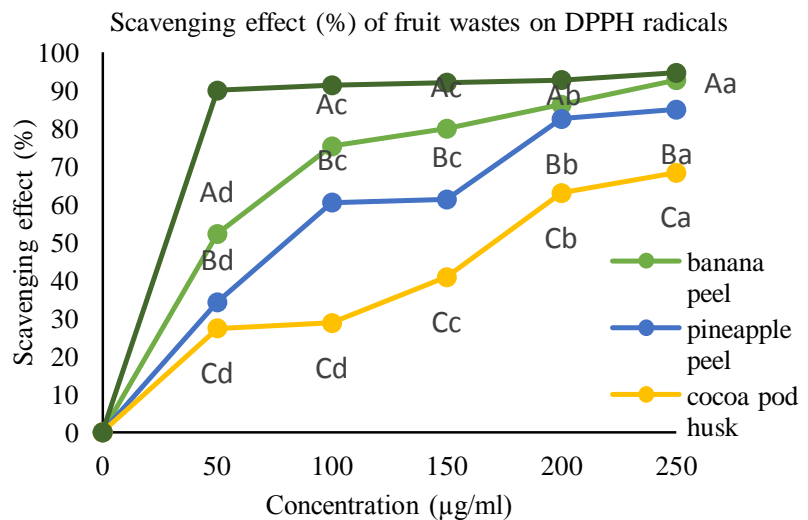

Fig 1: Scavenging effect of Cocoa pod husk, banana peel and pineapple peel.

Meanwhile, ascorbic acid and chlorogenic acid were determined by HPLC. Peak obtained were identified was by comparing its retention time. To conduct quantification of each compound obtained, calibration curve was constructed. Pineapple peel was found to have highest concentration of ascorbic acid (44.19 ppm) as shown in Table 1. Lower amount of ascorbic acids were detected in the banana peel (28.56 ppm) and cocoa pod husk $(29.25$ $\mathrm{ppm})$. Previous research found that ascorbic acid in pineapple stem $(0.73 \mathrm{mg} / 100 \mathrm{~mL})$ were higher compared to its core $(0.33$ $\mathrm{mg} / 100 \mathrm{~mL}$ ) after subjected to $380 \mathrm{~W}$ microwave drying [20].

Chlorogenic acid (CGA) is an important biologically active dietary polyphenol that is produced by certain plant species. Small amount of chlorogenic acid was identified in the cocoa pod husk and pineapple peel. However, the amount of CGA detected was not significant.

Effective concentration $\left(\mathrm{EC}_{50}\right)$ was determined for banana peel, pineapple peel and also for cocoa pod husk extracts. Table 2 shows the summary of the effective concentration of the samples. The results showed that banana peel has the lowest $\mathrm{EC}_{50}$ compared to pineapple peel and cocoa pod husk. Banana peel extract have powerful antioxidant activity compared to pineapple peel and cocoa pod husk. The strong antioxidant properties of banana peels could be an attributed to the presence of different antioxidant components. It is good to mention that a lower $\mathrm{EC}_{50}$ value represents more potent free radical inhibitory activity.

Table 2: Effective concentration

\begin{tabular}{ll}
\hline Sample & $\mathrm{EC}_{50}(\mu \mathrm{g} / \mathrm{ml})$ \\
\hline Banana peel & 49 \\
Pineapple peel & 80 \\
Cocoa pod husk & 170 \\
\hline
\end{tabular}

\subsection{Antimicrobial activity}

Insignificant differences were detected for antimicrobial properties of banana peel and cocoa pod husk against Staphylococcus aureus at concentration $25 \mathrm{mg} / \mathrm{mL}$ and $20 \mathrm{mg} / \mathrm{mL}$ as indicated in Table 3 .
Cocoa pod husk also showed good antimicrobial properties against $S$. aureus with $9.67 \mathrm{~mm}$ at $25 \mathrm{mg} / \mathrm{ml}$ and $8.00 \mathrm{~mm}$ at lower concentration $20 \mathrm{mg} / \mathrm{ml}$.

Table 3: Antimicrobial activity against Staphylococcus aureus

\begin{tabular}{cccccc}
\hline Sample & \multicolumn{5}{c}{ Inhibition zone $(\mathbf{m m})$} \\
\cline { 2 - 6 } & $\begin{array}{c}\mathbf{1 5} \\
\mathbf{m g} /\end{array}$ & $\begin{array}{c}\mathbf{2 0} \\
\mathbf{m g} / \mathbf{m l}\end{array}$ & $\begin{array}{c}\mathbf{2 5} \\
\mathbf{m g} / \mathbf{m l}\end{array}$ & $\begin{array}{c}\text { Posi } \\
\text { tive }\end{array}$ & $\begin{array}{c}\text { Nega- } \\
\text { tive }\end{array}$ \\
\hline $\begin{array}{c}\text { Banana } \\
\text { peel }\end{array}$ & NIZ & $9.67 \pm 0.58^{\text {ab }}$ & $11.67 \pm 1.53^{\text {a }}$ & 35 & NIZ \\
$\begin{array}{c}\text { Pineapple } \\
\text { peel }\end{array}$ & NIZ & NIZ & NIZ & 35 & NIZ \\
$\begin{array}{c}\text { Cocoa pod } \\
\text { husk }\end{array}$ & NIZ & $8.00 \pm 1.73^{\mathrm{b}}$ & $9.67 \pm 0.58^{\text {ab }}$ & 35 & NIZ \\
\hline
\end{tabular}

Banana peel showed lower inhibition zone against $E$. coli at high concentration $(25 \mathrm{mg} / \mathrm{ml})$ with $7.67 \mathrm{~mm}$ compared to cocoa pod husk $(10.33 \mathrm{~mm})$ as shown in Table 4 . Pineapple peel does not showed any inhibition zone against both tested bacteria.

\begin{tabular}{cccccc}
\multicolumn{5}{c}{ Table 4: Antimicrobial activity against Escherichia coli } \\
\hline Sample & \multicolumn{5}{c}{ Inhibition zone (mm) } \\
\cline { 2 - 6 } & $\begin{array}{c}\mathbf{1 5 m g /} \\
\mathbf{~ m l}\end{array}$ & $\mathbf{2 0 m g / m l}$ & $\mathbf{2 5 m g / m l}$ & $\begin{array}{c}\text { Posi- } \\
\text { tive }\end{array}$ & $\begin{array}{c}\text { Neg- } \\
\text { ative }\end{array}$ \\
\hline Banana & $6.67 \pm$ & $7.33 \pm$ & $7.67 \pm$ & 17.5 & NIZ \\
peel & $0.58^{\mathrm{c}}$ & $0.58^{\mathrm{bc}}$ & $0.58^{\mathrm{bc}}$ & & \\
$\begin{array}{c}\text { Pineapple } \\
\text { peel }\end{array}$ & $\mathrm{NIZ}$ & $\mathrm{NIZ}$ & $\mathrm{NIZ}$ & 17.5 & $\mathrm{NIZ}$ \\
$\begin{array}{c}\text { Cocoa pod } \\
\text { husk }\end{array}$ & $7.33 \pm$ & $9.33 \pm$ & $10.33 \pm$ & 17.5 & $\mathrm{NIZ}$ \\
\hline
\end{tabular}

Antimicrobial activity of the extracts also was tested against fungi (Penicillium). Positive control used was antibiotic known as nystatin. Nystatin showed great inhibition zone with $10.2 \mathrm{~mm}$ diameter. The result showed that cocoa pod husk, banana peel and pineapple peel does not show any inhibition (Table 5). However, methanolic extract of banana leaves showed stronger antifungal properties as compared to nystatin [19].

Table 5: Antimicrobial activity against Penicillium

\begin{tabular}{cccccc}
\hline Sample & \multicolumn{5}{c}{ Inhibition zone (mm) } \\
\cline { 2 - 6 } & $\mathbf{1 5 m g / m l}$ & $\mathbf{2 0 m g / m l}$ & $\mathbf{2 5 m g / m l}$ & Positive & Negative \\
\hline $\begin{array}{c}\text { Banana } \\
\text { peel }\end{array}$ & NIZ & NIZ & NIZ & 10.2 & NIZ \\
$\begin{array}{c}\text { Pineapple } \\
\text { peel }\end{array}$ & NIZ & NIZ & NIZ & 10.2 & NIZ \\
$\begin{array}{c}\text { Cocoa } \\
\text { pod husk }\end{array}$ & NIZ & NIZ & NIZ & 10.2 & NIZ \\
\hline
\end{tabular}

\subsubsection{Minimum Inhibition Concentration (MIC) and Mini- mum Bactericidal Concentration (MBC)}

Minimum inhibition concentration (MIC) refer to the least concentration of antibacterial agent that affects bacteria resistance and supress colonies growth. MIC of the extracts was tested by choosing the lowest concentration of extracts that showed inhibition zone. Table 6 shows that banana peel and cocoa pod husk extracts at $7.5 \mathrm{mg} / \mathrm{ml}$ shows clear broth indicates the lowest concentration that able to inhibit growth of $E$. coli. Banana peel at $5 \mathrm{mg} / \mathrm{ml}$ able to inhibit the growth of $S$. aureus and cocoa pod husk at $10 \mathrm{mg} / \mathrm{ml}$ able to inhibit growth of $S$. aureus.

Table 6: Minimum inhibition concentration of banana peel and cocoa pod husk extract

\begin{tabular}{ccc}
\hline & \multicolumn{2}{c}{ Minimum Inhibition Concentration (MIC) } \\
\cline { 2 - 3 } & Escherichia coli & $\begin{array}{c}\text { Staphylococcus } \\
\text { aureus }\end{array}$ \\
\hline Banana peel & $7.5 \mathrm{mg} / \mathrm{ml}$ & $5 \mathrm{mg} / \mathrm{ml}$ \\
Cocoa pod husk & $7.5 \mathrm{mg} / \mathrm{ml}$ & $10 \mathrm{mg} / \mathrm{ml}$ \\
\hline
\end{tabular}

Table 7 showed the Minimum bactericidal concentration (MBC). The lowest concentration of extract that yield no growth was rec- 
orded as MBC. In other word, MBC is the lowest concentration that able to kill the growth of bacteria. Broth dilution from MIC was subculture onto MHA plate and plate that does not show any bacterial growth indicates as MBC. Banana peel and cocoa pod husk showed potentially bactericidal activity against the tested pathogenic bacteria E.coli with $\mathrm{MBC} 15 \mathrm{mg} / \mathrm{ml}$ and while $\mathrm{MBC}$ against S.aureus was $10 \mathrm{mg} / \mathrm{ml}$.

Table 7: Minimum bactericidal concentration (MBC) of banana peel and cocoa pod husk extract

\begin{tabular}{ccc}
\hline & \multicolumn{2}{c}{ Minimum Bactericidal Concentration (MBC) } \\
\cline { 2 - 3 } & Escherichia coli & $\begin{array}{c}\text { Staphylococcus } \\
\text { aureus }\end{array}$ \\
\hline Banana peel & $15 \mathrm{mg} / \mathrm{ml}$ & $10 \mathrm{mg} / \mathrm{ml}$ \\
Cocoa pod husk & $15 \mathrm{mg} / \mathrm{ml}$ & $10 \mathrm{mg} / \mathrm{ml}$ \\
\hline
\end{tabular}

\section{Conclusion}

In conclusion, banana peel exhibited antioxidant activity with promising amount of total phenolic contents (154.50 mg GAE/g). Banana peels have higher antioxidant activity $(92.74 \%$ at a concentration of $250 \mu \mathrm{g} / \mathrm{mL}$ ) in comparison with pineapple peel and cocoa pod husk. Banana peel can be considered as a good antioxidant which can be developed as new food product. Significantly higher ascorbic acid was found in pineapple peel (44.19 ppm) compared to banana peel (28.56 ppm). Banana peel and cocoa pod husk showed excellent antimicrobial activity by inhibiting growth of Escherichia coli and Staphylococcus aureus in agar diffusion method. Both of banana peel and cocoa pod husk further can be considered as a good antimicrobial material against both gram positive and negative bacteria that can be developed as antimicrobial agent in food preservation.

\section{Acknowledgement}

The authors would like to thank the Bestari Grant Scheme: 600IRMI/DANA 5/3/BESTARI (125/2018) from Universiti Teknologi MARA. The authors would like to thank the facilities and technical assistance from lab staffs from Universiti Teknologi MARA. The authors have no competing conflicts of interest.

\section{References}

[1] Ibrahim, U. K., Kamarrudin, N., Suzihaque, M. U. H., \& Hashib, S A. (2017). Local fruit wastes as a potential source of natural antioxidant: An Overview.In IOP Conference Series: Materials Science and Engineering (Vol. 206, No. 1, p. 012040). IOP Publishing.

[2] Joshi, V. K., Kumar, A., \& Kumar, V. (2012). Antimicrobial, antioxidant and phyto-chemicals from fruit and vegetable wastes: A review. International Journal of Food and Fermentation Technology, 2(2), 123

[3] Deng, G., Shen, C., Xu, X. R., Kuang, R. D., Guo, Y. J., Zeng, L. S., Gao, L., Lin, X., Xie, J., Xia, E., Li, S., Wu, S., Chen, F., Ling, W., $\& \mathrm{Li}$, S. (2012). Potential of fruit wastes as natural resources of bioactive compounds. International Journal of Molecular Sciences, 13(7), 8308-8323.

[4] Yusof, F., Khanahmadi, S., Amid, A., \& Mahmod, S. S. (2016) Cocoa pod husk, a new source of hydrolase enzymes for preparation of cross-linked enzyme aggregate. SpringerPlus, 5(1), 57.

[5] Azizah, O., Ismail, A., Ghani, N. A., \& Adenan, I. (2007). Antioxidant capacity and phenolic content of cocoa beans. Food Chemistry, 100(4), 1523-1530.

[6] Padam, B. S., Tin, H. S., Chye, F. Y., \& Abdullah, M. I. (2014). Banana by-products: an under-utilized renewable food biomass with great potential. Journal of Food Science and Technology, 51(12), 3527-3545.

[7] Kapadia, S. P., Kapadia, S. P., Pudakalkatti, P. S., \& Shivanaikar, S. (2015). Detection of antimicrobial activity of banana peel (Musa paradisiaca L.) on Porphyromonas gingivalis and Aggregatibacter actinomycetemcomitans: A vitro study. Contemporary Clinical Dentistry, 6(4), 496.
[8] Upadhyay, A., Lama, J. P., \& Tawata, S. (2013). Utilization of pineapple waste: a review. Journal of Food Science and Technology Nepal, 6, 10-18.

[9] Hajar, N., Zainal, S., Nadzirah, K. Z., Roha, A. S., Atikah, O., \& Elida, T. T. (2012). Physicochemical properties analysis of three indexes pineapple (Ananas comosus) peel extract variety N36. APCBEE Procedia, 4, 115-121.

[10] Balasundram, N., Sundram, K., \& Samman, S. (2006). Phenolic compounds in plants and agri-industrial by-products: Antioxidant activity, occurrence, and potential uses. Food Chemistry, 99(1), 191-203.

[11] Ibrić, A., \& Ćavar, S. (2014). Phenolic Compounds and Antioxidant Activity of Cocoa and Chocolate Products. Bulletin of the Chemists and Technologists of Bosnia and Herzegovina, 42, $37-40$.

[12] Raseetha, S., Nurul-Nabilah, M., Zulkifli, M. F. and Ismail, W. I. W. (2017). Inhibition of lipid accumulation in 3T3-L1 adipocytes by chlorogenic acid derived from green coffee (Robusta sp.) beans and pulps, Malaysian Applied Biology Journal, 46(4):1-8

[13] Daud, M. N. H., Fatanah, D. N., Abdullah, N., \& Ahmad, R. (2017) Evaluation of antioxidant potential of Artocarpus heterophyllus L. $\mathrm{J} 33$ variety fruit waste from different extraction methods and identification of phenolic constituents by LCMS. Food Chemistry, 232, 621-632.

[14] Azlim Almey, A. A., Ahmed Jalal Khan, C., Syed Zahir, I., Mustapha Suleiman, K., Aisyah, M. R., \& Kamarul Rahim, K. (2010). Total phenolic content and primary antioxidant activity of methanolic and ethanolic extracts of aromatic plants' leaves. International Food Research Journal, 17(4).

[15] Hlila, M. B., Majouli, K., Jannet, H. B., Aouni, M., Mastouri, M., \& Selmi, B. (2017). Antimicrobial activity of Tunisian Euphorbia paralias L. Asian Pacific Journal of Tropical Biomedicine, 7(7), 629-632.

[16] Aboul-enein, A. M., Salama, Z. A., Gaafar, A. A., Aly, H. F., Faten, A., \& Ahmed, H. A. (2016). Identification of phenolic compounds from banana peel (Musa paradaisica L.) as antioxidant and antimicrobial agents, Journal of Chemical and Pharmaceutical Research, 8(4), 46-55.

[17] Li, T., Shen, P., Liu, W., Liu, C., Liang, R., Yan, N., \& Chen, J. (2014). Major polyphenolics in pineapple peels and their antioxidant interactions. International Journal of Food Properties, 17(8), 1805-1817.

[18] Azila, A. K., Azrina, A., \& Puziah, H. (2014). Antioxidant properties of cocoa pods and shells. Malaysian Cocoa Journal, 8, 49-56.

[19] Harith, S.S., Yasim, N.H.M., Harun, A., Omar, W.S.A.W., Musa, M.S. (2018). Phytochemical screening, antifungal and antibacterial activities of Musa acuminata plant. Malaysian Journal of Analytical Sciences, 22(3), 452-457

[20] Zaki, N.A.M., Rahman, N.A., Zamanhuri, N.A., Hashib, S.A. (2017). Ascorbic acid content and proteolytic enzyme activity of microwave-dried pineapple stem and core. Chemical Engineering Transactions, 56, pp. 1369-1374 